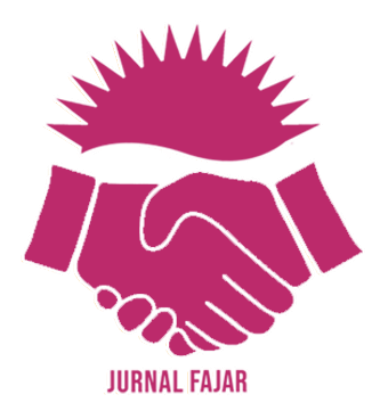

\title{
METODE PEMBINAAN “MIOS” UNTUK MENINGKATKAN PENDIDIK PROFESIONAL DALAM PROFESIONAL LEARNINg GENERASI USIA EMAS DI SMP PRAKARYA SANTI ASROMO MAJALENGKa PROVINSI JaWA BARAT ${ }^{*}$
}

\author{
Zaenul Slam \\ Universitas Islam Negeri Syarif Hidayatullah Jakarta \\ Email: zaenul_slam@uinjkt.ac.id

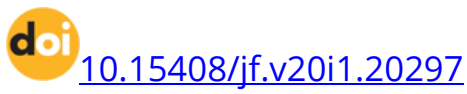

\begin{abstract}
:
This article examines the "MIOS" coaching method at Prakarya Santi Asromo Majalengka Middle School, West Java Province. The results of this community service show that: First, monitoring as an activity in the early stages of service treatment shows that the implementation of professional learning for the golden age generation has not run optimally. Second, the results of in-service by service providers in the form of workshops have an impact on increasing the professionalism of educators. Third, the implementation of on-service by servants in the form of classroom observations has an impact on increasing professional educators in the implementation of professional learning for the golden age generation. The increase in professional educators in the implementation of professional learning is seen in the improvement of the pedagogical competence of educators, especially in the implementation of learning. In addition, it also has an impact on improving the quality of the process and learning outcomes of students. Therefore, it is necessary to develop professional educators in the implementation of professional learning for the golden age generation with the MIOS coaching method.
\end{abstract}

Keywords: Professional Teacher, Professional Learning, MIOS.

* Diterima 23 November 2019, Revisi 1 Desember 2019, Diterbitkan 30 Januari 2020. 


\begin{abstract}
Abstrak:
Artikel ini mengkaji mengenai metode pembinaan "MIOS" di SMP Prakarya Santi Asromo Majalengka Provinsi Jawa Barat. Hasil pengabdian masyarakat ini menunjukkan bahwa: Pertama, monitoring sebagai kegiatan tahap awal treatment pengabdi menunjukkan bahwa implementasi professional learning untuk generasi usia emas belum berjalan dengan optimal. Kedua, hasil in service oleh pengabdi dalam bentuk workshop memberikan dampak terhadap peningkatan profesionalisme pendidik. Ketiga, Pelaksanaan on service oleh pengabdi dalam bentuk observasi kelas berdampak pada peningkatan pendidik profesional dalam implementasi professional learning untuk generasi usia emas. Peningkatan pendidik profesional dalam implementasi professional learning tampak dalam peningkatan kompetensi pedagogik pendidik terutama dalam pelaksanaan pembelajaran. Selain itu berdampak pula pada peningkatan mutu proses dan hasil pembelajaran peserta didik. Oleh karena itu, maka diperlukan pembinaan pendidik professional dalam implementasi professional learning untuk generasi usia emas dengan metode pembinaan MIOS.
\end{abstract}

Kata Kunci: Pendidik Profesional, Professional Learning, MIOS 


\section{Pendahuluan}

Gelombang peradaban keempat yang saat ini kenal dengan era industri 4.0 menuntut mengadaftasi seluruh kerangka pikir dan perangkat kerja pada setiap dimensi kehidupan. Tak terkecuali dalam pengelolaan dunia pendidikan di tanah air. Sebagaimana ketahui dan sadari bersama bahwa gerak perkembangan dunia pendidikan mengikuti deret hitung sementara perkembangan eksternal mengikuti deret ukur. Hal tersebut berimplikasi pada terjadinya kesenjangan yang melahirkan 2 (dua) tantangan mendasar yang dihadapi dunia pendidikan secara serempak yaitu daya saing global dan pemerataan mutu pendidikan di tanah air.[1]

Ketika berbicara daya saing, pada tataran tertentu sebenarnya sedang berbicara tentang human capital yang muaranya kembali ke dunia pendidikan. Salah satu mata rantai pada bagian ini yang menjadi prioritas adalah bagaimana pembelajaran mengarah pada pengembangan professional learning untuk mendukung kebutuhan Sumber Daya Manuasi (SDM) yang memiliki daya saing global. Artinya pembelajaran perlu mengembangkan pada kinerja belajar peserta didik yang mendorong daya belajar kritis, kreatif, aktif, dan produktif yang relevan dengan kebutuhan Sumber Daya Manusia pada era ini . Untuk menjadikan peserta didik professional learning, pendidik perlu memfasilitasi proses belajar yang diarahkan untuk mengembangkan daya kritis peserta didik (critical thingking in learning), daya kreatif peserta didik (creative thingking in learning), daya pemecahan masalah (problem solving in learning), pembelajaran aktif (active learning) dan daya berpikir ilmiah peserta didik (scientific thingking in learning). Peserta didik profesional akan lahir dengan hadirnya guru profesional.

Berdasarkan hal tersebut di atas, bahwa untuk menghadirkan peserta didik professional learning membutuhkan guru profesional. Seperti yang disampaikan oleh Ratnasari salah satu yang memengaruhi mutu pendidikan yaitu profesionalisme guru karena guru merupakan penentu dari keberhasilan dan kegagalan dari suatu proses pembelajaran sehingga hal tersebut akan berpengaruh pada masa depan peserta didik. keberadaan dan kehadiran pendidik, sebagai key actor in the learning process, yang profesional serta memiliki karakter kuat dan cerdas merupakan suatu kebutuhan.[2] Pendapat tersebut diperkuat oleh Rusman (2010) yang menyatakan bahwa pendidik profesional harus memiliki salah satunya kompetensi profesional, artinya ia memiliki pengetahuan yang luas serta dalam dari bidang studi yang akan diajarkan serta penguasaan metodologis dalam arti memiliki pengetahuan konsep teoretik, mampu memiliki metode yang tepat serta mampu menggunakan berbagai metode dalam proses belajar mengajar. Pendidik pun harus memiliki pengetahuan yang luas tentang landasan kependidikan dan pemahaman terhadap subjek didik.[3] Profesionalisme guru adalah guru yang memiliki kompetensi profesional. Kompetensi profesional yang dimaksud dalam hal ini merupakan kemampuan guru mengusai materi pelajaran 
secara luas dan mendalam, termasuk penguasaan kemampuan akademik lainnya yang berperan sebagai pendukung profesionalisme guru. Kemampuan akademik tersebut antara lain, memiliki kemampuan dalam menguasai ilmu, jenjang dan jenis pendidikan yang sesuai dengan bidangnya. Dengan implementasi professional learning oleh para pendidik profesional di kelas-kelas diyakini akan mampu mewujudkan visi Indonesia Emas tahun 2045, yakni kejayaan secara moral dan spiritual dan sekaligus kejayaan ekonomi bagi seluruh komponen bangsa.

Menurut Aminah, Khairudin, dan Husen menetapkan guru yang profesional memiliki lima ciri, yaitu:[4] 1) Mempunyai komitmen pada peserta didik dan proses belajarnya, 2) Menguasai secara mendalam bahan pelajaran yang akan diajarkan, serta cara penyampaian kepada siswa, 3) Bertanggung jawab memantau hasil belajar siswa melalui berbagai teknik evaluasi, 4) Mampu berpikir sistimatis tentang apa yang dilakukannya, megadakan refleksi dan koreksi, belajar dari pengalaman dan memperhitungkan dampaknya pada proses belajar mengajar, 5) Seyogyanya merupakan bagian dari masyarakat belajar dalam lingkungan profesinya, sehingga terjadi interaksi yang luas dan profesional.

Guru yang profesional dalam mengajar adalah guru yang mampu membuat perencanaan pembelajaran berupa pembuatan analisis materi pembelajaran (AMP). Program tahunan, program semester, satuan pembelajaran (SP) dan rencana pembelajaran (RP). Setelah adanya perencanaan pengajaran, maka guru juga dituntut memiliki kemampuan dalam melaksanakan proses belajar mengajar. Menurut Nasution ada tiga cara yang harus dimiliki guru profesional dalam mengelola proses pembelajaran, yaitu:[5] 1) Menyampaikan materi pelajaran secara sistimatis, 2) Mengatur lalu lintas komunikasi antara guru dengan siswa dan antara siswa dengan siswa, dan 3). Mengarahkan pembicaraan atau diskusi dalam kelas yang sesuai dengan tujuan pembelajaran. Selanjutnya setelah pelaksanaan proses belajar mengajar, guru melaksanakan evaluasi pengajaran yang dapat memberikan informasi mengenai tingkat ketercapaian program pengajaran dan daya serap siswa setelah selesainya proses pembelajaran dilaksanakan.

Merujuk dari apa yang diuraikan di atas, sejatinya setiap pendidik perlu menerima konsekuensi sebagai bukti tanggung jawab profesi dalam implementasi professional learning untuk menghadirkan generasi usia emas. Professional learning perlu diterapkan oleh pendidik profesional dengan cara memfasilitasi proses belajar profesional, artinya melalui proses pembelajaran profesional, pendidik memfasilitasi, membimbing peserta didik untuk mencari, menemukan, menganalisis, sistesis, dan bahkan mengevaluasi sampai pada kreasi yang dilakukan secara mandiri.

Namun, kenyataannya sungguh berbeda dengan keharusan menjadi guru profesional. Hasil pengamatan awal, peneliti menemukan beberapa indikator 
rendahnya profesional guru dalam mengajar yaitu: 1) Adanya guru yang kurang profesional dalam menyusun program pengajaran berupa Analisis Materi Pelajaran (AMP), program tahunan, program semester, Satuan Pelajaran (SP), dan Rencana Pelaksanaan Pembelajaran (RPP), 2) Kurangnya profesional guru melaksanakan proses pembelajaran tentang metode mengajar, menggunakan media mengajar, dan melakukan pendekatan dengan peserta didik, dan 3) Kurangnya profesional guru melaksanakan evaluasi dari segi kemampuan dalam membuat dan menjabarkan kisi- kisi soal, membuat pembobotan terhadap itemitem soal, baik dari sisi ranah (kognitif, afektif, dan psikomotor), maupun dari tingkat kesukaran (sukar, sedang, mudah), dan menjabarkan kontruksi tes dalam bentuk item-item soal secara jelas dan operasional (terukur). Begitu juga dalam hal professional learning peserta didik masih terbatas pada beberapa peserta didik tertentu dan sebagian besar peserta didik belajar apa adanya dengan tidak menunjukkan keseriusan dalam belajarnya akhirnya hasil belajar mereka kurang memuaskan seperti rendahnya nalar kritis dan nalar kreatif peserta didik. Hal ini akibat dari terbatasnya kemampuan guru menerapkan pembelajaran yang memberikan kesempatan kepada peserta didik dalam berbagai mata pelajaran untuk mengembangkan potensi-potensi peserta didik memiliki kemampuan berpikir holistik, kreatif, objektif, dan logis.[6] Untuk itu sekolah telah melakukan pembinaan terhadap para guru namun hasilnya belum berdampak pada implementasi professional learning untuk generasi usia emas.

Berdasarkan persoalan tersebut di atas, muncul pertanyaan hal-hal apa sajakah sebenarnya yang menjadi penyebab bahwa pembinaan pendidik kurang berdampak pada implementasi professional learning untuk generasi usia emas.? Pertanyaan tersebut mungkin menggelitik. Setidaknya ada tiga alasan empiris untuk menjawab pertanyaan itu. Pertama, pembinaan pendidik seringkali tidak berbasis pada masalah nyata kondisi pendidik dalam pembelajaran di kelas. Padahal kondisi pendidik di setiap kelas/sekolah belum tentu sama baik dari aspek kualifikasi akademik maupun kompetensinya. Kedua, hasil pembinaan di sekolah atau di Musyawarah Guru Mata Pelajaran (MGMP) hanya menjadi pengetahuan saja, kurang diimplementasikan pada pembelajaran di kelas atau walaupun diimplementasikan hanya diterapkan sekali saja, dua kali dan selanjutnya kembali "seperti dulu lagi, meminjam istilah dari bagian lirik lagu Dian Pisesa adalah "aku masih seperti yang dulu". Pendidik kembali seperti biasanya mengajar dominan menggunakan metode ceramah, tugas sesekali diskusi.

Ketiga, metode pembinaan guru saat ini cenderung masih dominan ceramah yang diakhiri tanya jawab. Dengan metode pembinaan seperti itu, guru hanya disiapkan untuk mendengarkan, dan mau menerima seluruh informasi dan mentaati segala petunjuk kepala sekolah dan pengawas sekolah yang mengakibatkan guru tidak kreatif, mandiri, dan inovatif. Dengan pola 
pembinaan seperti ini nampaknya akan menyulitkan guru ketika menghadirkan peserta didik professional learning di kelas-kelas. Pada akhirnya sebagian besar guru tetap saja dominan menampilkan pembelajaran ceramah pemberian tugas, dan sesekali diskusi. Dengan pola pembelajaran seperti itu, peserta didik hanya disiapkan mendengarkan, menerima seluruh informasi, dan menaati segala peraturan gurunya yang mengakibatkan mereka tidak memiliki keberanian mengemukakan pendapat, tidak kreatif, tidak mandiri, apalagi berpikir inovatif dan problem solving. Budaya dan mentalitas peserta didik seperti ini berkorelasi dengan lowout come learning quality.

Berbagai persoalan pembelajaran seperti tersebut di atas, menunjukkan bahwa pembinaan pendidik yang dilakukan selama ini di sekolah tersebut belum maksimal memberikan dampak yang signifikan terhadap implementasi professional learning untuk generasi usia emas. Pembinaan pendidik berarti serangkaian usaha bantuan kepada guru, terutama bantuan yang berujud layanan profesional yang diberikan oleh kepala sekolah, pemilik sekolah, pengawas dan pembina lainnya untuk meningkatkan mutu proses dan hasil belajar peserta didik. Persoalan ini sangat serius dan persoalan tersebut tidak boleh dibiarkan dan perlu dicarikan solusi yang terbaik.

Berdasarkan hal tersebut, maka pihak sekolah dan pengusul kegiatan pengabdian ini merencanakan kegiatan " Metode Pembinaan "MIOS" Untuk Meningkatkan Pendidik Profesional Dalam Profesional Learning Generasi Usia Emas Di SMP Prakarya Santi Asromo Majalengka Provinsi Jawa Barat". Pembinaan guru berarti serangkaian usaha bantuan kepada guru, terutama bantuan yang berujud layanan profesional yang diberikan oleh kepala sekolah, pemilik sekolah, pengawas dan pembina lainnya untuk meningkatkan proses dan hasil belajar peserta didik.[7] "MIOS" merupakan singkatan dari : $\mathrm{M}=$ Monitoring, $\mathrm{I}=\mathrm{In}, \mathrm{O}=\mathrm{On} \mathrm{S}=$ Service. MIOS ini merupakan model pembinaan pendidik dilaksanakan dengan tahapan Monitoring, In Service dan, On Service.

Apa yang disebut monitoring? Menurut Triwiyanto bahwa pengertian monitoring di sekolah sering juga dipertukarkan maknanya dengan supervisi pendidikan.[8] Supervisi pendidikan adalah segenap bantuan yang diberikan oleh seseorang (di sekolah biasanya dilakukan guru senior, kepala sekolah, dan pengawas sekolah) dalam mengembangkan situasi belajar mengajar disekolah kearah yang lebih baik. Monitoring berguna untuk melihat dan memantau perkembangan suatu pekerjaan atau transaksi yang sedang berjalan.[9] Monitoring merupakan kegiatan untuk mengetahui apakah program yang telah dibuat berjalan dengan baik sesuai dengan yang direncanakan, adakah hambatan yang terjadi dan bagaimana para pelaksana program itu mengatasi hambatan tersebut. Monitoring terhadap hasil perencanaan yang sedang dilaksanakan menjadi alat pengendalian yang baik terhadap seluruh proses implementasi. Monitoring lebih menekankan pada pemantauan terhadap proses pelaksanaan. 
Kementerian Pendidikan dan Kebudayaan Republik Indonesia menyatakan bahwa monitoring/pemantauan pada pengawasan akademik adalah kegiatan pengawasan untuk mengetahui data dan informasi tentang pelaksanaan kesesuaian dan ketercapaian standar kompetensi lulusan (SKL), standar isi (SI), standar proses, dan standar penilaian dalam perencanaan dan pelaksanaan pembelajaran.[10]

Monitoring merupakan prosedur penilaian yang secara deskriptif bertujuan untuk mengidentifikasi dan/atau mengukur dampak dari kegiatan yang sedang berjalan tanpa mempertanyakan hubungan kausalitas. Monitoring dalam konteks ini adalah monitoring implementasi professional learning untuk generasi usia emas sebagai bagian dari monitoring standar proses di SMP Prakarya Santi Asromo.

Secara lebih terperinci monitoring bertujuan untuk: (a) mengumpulkan data dan informasi yang diperlukan; (b) memberikan masukan tentang kebutuhan dalam melaksanakan program; (c) mendapatkan gambaran ketercapaian tujuan setelah adanya kegiatan; (d) memberikan informasi tentang metode yang tepat untuk melaksanakan kegiatan; (e) mendapatkan informasi tentang adanya kesulitan-kesulitan dan hambatan-hambatan selama kegiatan; (f) memberikan umpan balik bagi sistem penilaian program; dan (g) memberikan pernyataan yang bersifat penandaan berupa fakta dan nilai. Monitoring dalam konteks ini adalah monitoring implementasi professional learning untuk generasi usia emas sebagai bagian dari monitoring standar proses di SMP Prakarya.

In service merupakan salah satu model pembinaan pendidik profesional.In service dalam pembinaan profesional salah satunya bertujuan untuk menindak lanjuti temuan hasil monitoring.Dalam konteks ini, In service diperlukan dalam penguatan implementasi professional learninguntuk generasi usia emas. Workshop merupakan salah satu model in service.

Apakah workshop itu? Kata workshop berasal dari bahasa Inggris yang berarti lokakarya yang mengandung pengertian suatu acara di mana beberapa orang berkumpul untuk memecahkan masalah tertentu dan mencari solusinya. Sebuah lokakarya adalah pertemuan ilmiah yang kecil. Lokakarya adalah pertemuan antara para ahli (pakar) untuk membahas masalah praktis atau yang bersangkutan dengan pelaksanaan dalam bidang keahliannya adalah sebuah kegiatan yang dilakukan oleh beberapa orang yang memiliki kompetensi tertentu berkumpul untuk membahas masalah tertentu dan mengajari para peserta workshop. Workshop adalah gabungan antara teori dan praktik.

Workshop merupakan salah satu metode pembinaan untuk pendidik profesional. Seperti yang disampaikan Depdiknas bahwa workshop atau lokakarya merupakan salah satu metode yang dapat ditempuh fasilitator/narasumber dalam melakukan supervisi akademik. Pendapat tersebut diperkuat oleh Suprayekti dan Anggraeni bahwa lokakarya atau workshop adalah pertemuan orang yang bekerja sama dalam kelompok kecil dan dibatasi pada 
masalah yang dihadapi sendiri.[11] Penyelenggaraan workshop ini disesuaikan dengan tujuan atau urgensinya. Dalam workshop ini bersifat kelompok dan dapat melibatkan kepala sekolah dan guru.

Nilai lebih workshop adalah kegiatan yang menggabungkan antara teori dan praktik. Seperti yang disampaikan oleh Slam (2015) bahwa kelebihan workshop sebagai berikut. (1) peserta mendapatkan keterangan teoretis yang luas dan mendalam tentang masalah yang dibahas; (2) peserta mendapatkan petunjuk-petunjuk praktis untuk melaksanakan tugasnya; (3) peserta dibina untuk bersikap dan berfikir secara ilmiah; (4) terpupuknya kerja sama antar peserta. Oleh karena itu, dengan workshop diyakini efektif dapat meningkatkan pendidik professional dalam implementasi profesional learning untuk generasi usia emas.

Berdasarkan nilai lebih tersebut, bahwa dalam workshop ini, peserta difasilitasi oleh fasilitator untuk belajar memahami teori model-model pembelajaran abad 21 dan selanjutnya peserta dibimbing oleh fasilitator praktik menyusun perencanaan pmbelajaran yang berbasis model pembelajaran abad 21 . Hal inilah merupakan nilai lebih dilaksanaknnya workshop peningkatan pendidik profesional learning dalam impelemntasi professional learning untuk generasi usia emas. Dimana dalam implementasinya, para guru menerima informasi tentang model-model pembelajaran abad 21 dan sekaligus guru praktik langsung menyusun rencana pelaksanaan pembelajaran berbasis model-model pembelajaran abad 21 yang dibimbing langsung oleh peneliti.

Peningkatan profesionalisme tenaga pendidik tidak hanya cukup dengan workshop semata namun diperlukan on service dalam bentuk kegiatan supervisi akademik, yaitu untuk membantu guru mengembangkan kemampuan mencapai tujuan pembelajaran yang direncanakan bagi murid-muridnya. Dengan demikian tujuan yang paling pokok dalam supervisi pembelajaran bagaimana guru mencapai tujuan pembalajaran yang telah ditetapkan.

Tujuan supervisi akademik dalam konteks pengawasan proses pembelajaran adalah untuk mengetahui: (1) kompetensi guru dalam membuat persiapan atau perencanaan pembelajaran; (2) ketepatan dalam memilih pendekatan, model, metode, dan teknik pembelajaran sesuai dengan bahan ajar yang akan disampaikan kepada siswa; (3) kompetensi guru sebagai tenaga profesional dalam melaksanakan proses pembelajaran di dalam kelas; (4) kompetensi guru dalam mengembangkan intrumen penilaian dalam; (5) melaksanakan evaluasi, baik evaluasi selama proses pembelajaran atau evaluasi hasil belajar; (6) kemampuan guru dalam memberikan tindak lanjut pembelajaran kepada siswa; dan (7) kelengkapan administrasi pembelajaran yang diperlukan dalam rangka melaksanakan tugasnya sebagai seorang tenaga profesional dibidang pendidikan.[10] 
Supervisi akademik memiliki manfaat antara lain sebagai berikut: (1) Guru yang disupervisi akan mengetahui kelebihan dan kekurangan dalam membuat perencanaan pembelajaran; (2) Guru yang bersangkutan dapat mengetahui kelebihan dan kekurangan dalam melaksanakan proses pembelajaran di dalam kelas; (3) Guru yang bersangkutan akan mengetahui kelebihan dan kekurangannya dalam merencanakan dan mengembangkan instrumen penilaian pembelajaran; (4) sebagai bahan refleksi guru untuk menambah dan meningkatkan wawasan serta pengetahuan.[10]

Supervisi akademik yang digunakan oleh pengabdi dalam kegiatan On Service adalah dengan teknik observasi kelas, yaitu Pengabdi datang ke kelas untuk mengobservasi guru mengajar. Dengan kata lain, untuk melihat apa kekurangan atau kelemahan yang sekiranya perlu diperbaiki. Dengan teknik observasi kelas ini, pengabdi dapat mempengaruhi perilaku mengajar guru sehingga perilakunya semakin baik dalam mengelola proses belajar mengajar. Selanjutnya perilaku mengajar guru yang baik itu akan mempengaruhi perilaku belajar peserta didik. Dengan demikian, dapat disimpulkan bahwa tujuan akhir observasi kelas adalah terbinanya guru profesional dalam mengajar dan peserta didik belajar professional (professional learnin)..

Metode pembinaan MIOS ini merupakan salah satu model inovatif, ekonomis, dan lestari untuk pembinaan pendidik profesional. Dengan model pembinaan seperti ini, pengabdi terlebih dahulu melakukan monitoring kondisi implementasi professional learning terhadap beberapa orang pendidik. Hasil monitoring ini merupakan modal awal untuk setting kebutuhan pembinaan pendidik profesional oleh pengabdi selanjutnya. Berdasarkan kebutuhan pendidik ini, pengabdi melaksanakan In Service (pembinaan di sekolah bagi semua pendidik dalam bentuk workshop). Selanjutnya pengabdi melaksanakan On Service, yakni pengabdi melaksanakan pembinaan terhadap setiap pendidik di kelas-kelas melalui observasi kelas.

Dengan model "MIOS"ini diyakini efektif berdampak signifikan pada pendidik profesioanl dalam implementasi professional learning untuk generasi usia emas di SMP Prakarya yaitu: pertama, pendidik menjadi profesional dan mutu proses dan hasil pembelajaran meningkat. Kedua, pendidik memiliki banyak kesempatan berdialog tentang ide-ide pendidikan dalam praktek pembelajarannya sehingga dapat merubah perspektif tentang pembelajaran, dan belajar praktek pembelajaran dari perspektif peserta didik.

Tujuan pengabdian masyarakat ini adalah untuk meningkatkan pendidik profesioanl dalam professional learning generasi usia emas melalui metode pembinaan "MIOS" bagi guru SMP Prakarya Santi Asromo Majalengka Provinsi Jawa Barat

\section{Hasil dan Pembahasan}


Kegiatan pengabdian masyarakat berjudul "Peningkatan Pendidik Profesional Untuk Profesional Learning Generasi Usia Emas Melalui Metode pembinaan MIOS Bagi Guru SMP Prakarya Santi Asromo Majalengka Provinsi Jawa Barat telah dilaksanakan berlangsung selama tiga bulan, yakni bulan Januari sampai dengan bulan Maret 2018. Pertama, pada minggu kedua tanggal 15 Januari 2018 bertempat ruang pertemuan dilaksanakan monitoring oleh penulis tentang kondisi pembelajaran di SMP Prakarya fokus pada: (1) profil pendidik dari aspek kualifikasi dan kompetensi pendidik; (2) Administrasi pembelajaran guru; dan (3) pelaksanaan pembelajaran.Kedua, kegiatan in service dilaksanakan pada tanggal 26 Januari 2018 bertempat di SMP Prakarya. Kegiatan in service ini dilaksanakan dalam bentuk workshop selama satu hari untuk semua guru. Dalam kegiatan tersebut, peneliti mendapat undangansebagai nara sumber menyampaikan model-model pembelajaran dalam implementasi professional learning untuk generasi usia emas. Ketiga, pasca dilaksanakan workshop selanjutnya dilaksanakan on service pada awal Februari 2018 sampai dengan pertengahan Maret 2018 dalam bentuk observasi kelas sebagai model pembinaan guru dalam implementasi professional learning untuk generasi usia emas di ruangruang kelas untuk semua guru.

Seperti yang telah disampaikan di atas bahwa salah satu persoalan esensial dalam proses pembelajaran di SMP Prakarya Santri Asromo adalah: Pertama, kompetensi pendidik dalam implementasi professional learning masih beragam, dan peningkatan pendidik profesional sangat perlu dilakukan untuk menyiapkan generasi usia emas. Kedua, kepala sekolah dan pengawas sekolah belum melaksanakan pembinaan pendidik profesional secara maksimal karena cenderung menggunakan metode ceramah dan bersifat terpisah, yang seharusnya pembinaan pendidik profesional dilaksanakan secara berkelnjutan dengan menggunakan metode inovatif, kreatif, dan efektif.

Penyebab munculnya kedua persoalan seperti tersebut di atas adalah salah satunya belum optimal melakukan pembinaan pendidik profesional dalam implementasi professional learning. Oleh karena itu, optimalisasi pembinaan pendidik profesional merupakan kebutuhan utama dalam implementasi professional learning untuk generasi usia emas.

Berdasarkan persoalan tersebut di atas, maka peneliti melakukan langkahlangkah yang signifikan dan strategis dalam optimalisasi pembinaan pendidik profesional. Pengabdi tidak boleh berdiam diri tetapi perlu berangkat (MIOS) ke sekolah-sekolah atau ke kelas-kelas untuk melaksanakan pembinaan pendidik profesional di sekolah-sekolah secara berkelanjutan dengan metode inovatif, kreatif, dan efektif. Selain itu, pengabdi juga menyadari bahwa keberhasilan pembinaan untuk pendidik profesional diperlukan komitmen yang tinggi dari seorang pengabdi. Pembinaan pendidik profesional adalah panggilan profesional. . 
Metode/cara yang pengabdi gunakan untuk menyelesaikan masalah tersebut di atas dan langkah-langkahnya, peneliti beri nama metode pembinaan MIOS. Metode ini adalah metode inovatif pembinaan pendidik profesioanl dan diyakini efektif dapat meningkatkan pendidik profesional dalam implementasi professional learning untuk generasi usia emas.

\section{Hasil Monitoring dan Pembahasannya}

Kegitan monitoring ini dilaksanakan bertujuan untuk mengetahui sejauhmana kesiapan guru dalam implementasi pembelajaran pada semester tersebut. Monitoring ini bisa dikatakan sebagai cara peneliti melakukan pembinaan awal terhadap pendidik di sekolah tersebut. Dengan cara ini kiranya dapat memotret persiapan pendidik dalam pembelajaran di sekolah.

Salah satu prioritas utama peneliti dalam kegiatan monitoring standar proses di SMP Prakarya adalah melaksanakan monitoring tentang implementasi professional learning untuk generasi usia emas. Kegiatan monitoring dalam konteks ini untuk mengetahui apakah implementasi professional learning untuk generasi usia emas berjalan dengan baik sesuai rencana, adakah hambatan yang terjadi, dan bagaimana sekolah mengatasi hambatan tersebut. Kegiatan monitoring ini fokus pada bagaimana perencanaan pembelajaran dan bagaimana pelaksanaan pembelajaran di SMP Prakarya Santi Asromo. Hasil monitoring ini dapat dijadikan bekal awal pembinaan selanjutnya dalam implementasi professional learning untuk generasi usia emas.

Berikut ini adalah hasil monitoring implementasi professional learning untuk generasi usia emas di SMP Prakarya Santi Asromo. Apakah implementasi professional learning untuk generasi usia emas berjalan dengan baik di SMP Prakarya Santi Asromo? Adakah hambatan yang terjadi dalam implementasi professional learning untuk generasi usia emas? dan bagaimana sekolah mengatasi hambatan tersebut? Kenyataannya bahwa implementasi professional learning untuk generasi usia emas belum berjalan dengan optimal di SMP Prakarya Santi Asromo. Hambatannya adalah adanya keragaman kompetensi pedagogik guru dalam perencanaan dan pelaksanaan pembelajaran dalam implementasi professional learning untuk generasi usia emas. Keragaman tersebut tampak pada kemampuan guru dalam perencanaan dan pelaksanaan pembelajaran. Hasil monitoring ini menunjukkan bahwa faktor penyebab keragaman kemampuan guru tersebut adalah karena keragaman kualifikasi akademik guru, terbatasnya kegiatan pengembangan keprofesian berkelanjutan guru, dan komitmen guru dalam peningkatan mutu secara umum terbatas serta tidak pernah dilaksanakan observasi kelas oleh kepala sekolah secara berkelanjutan. Hasil monitoring ini sebagai pintu masuk pembinaan pendidik professional sesuai kebutuhaan pendidik itu sendiri. 
Untuk mengatasi persoalan seperti tersebut di atas, maka diperlukan pembinaan pendidik profesional berkelanjutan dalam implementasi professional learning dengan in service dan on service. In service dilaksanakan dalam bentuk workshop peningkatan pendidik dalam implementasi professional learning untuk generasi usia emas dan on servicedilaksanakan dalam bentuk supervisi kelas. Dalam workshop, peneliti sebagai nara sumber/fasilitator dan dalam observasi kelas, peneliti melaksanakan observasi kelas terhadap semua guru.

\section{Hasil In Service (workshop) dan Pembahasannya}

Berdasarkan hasil monitoring seperti tersebut di atas, diperlukan peningkatan pendidik profesional secara berkelanjutan dalam implementasi professional learning untuk generasi usia emas. Masukan peneliti mendapat respon yang sangat positif dari kepala sekolah dan yayasan. Kepala sekolah menganggap bahwa pengembangan keprofesian guru merupakan hal yang utama dalam implementasi professional learning untuk generasi usia emas. Beradasarkan hasil musyawarah antara kepala sekolah, yayasan, dan peneliti, in service learning dilaksanakan dalam bentuk workshop peningkatan profesionalisme Tenaga Pendidik Pondok Wufidah Santi Asromo. Workshop tersebut dilaksanakan pada tanggal 26 Januari 2018 bertempat di SMP Prakarya.

sebagai pengabdi dalam kegiatan workshop tersebut diundang sebagai nara sumber/fasilitator. Materi yang disampaikan oleh sebagai peneliti dalam workshop ini adalah model-model pembelajaran dan penilaian abad 21. Model ini diyakini efektif dapat meningkatkan pendidik profesional dalam implementasi professional learning untuk generasi usia emas di SMP Prakarya. Selanjutnya para peserta workshop diberi tugas menyusun perencanaan pembelajaran sesuai dengan mata pelajaran yang diampu dengan mengintegrasikan model pembelajaran abad 21 sebagai indikator implementasi professional learning untuk generasi usia emas.

Workshop ini tentunya memilki nilai lebih dan juga ada sisi kekurangannya. Beberapa nilai lebih dengan dilaksanakan workshop ini adalah hampir semua pendidik dapat membuat rancangan pembelajaran yang berorientasi implementasi professional learning untuk generasi usia emas. Hasil workshop ini adalah guru mampu menyusun rencana pembelajaran yang mengaktivasi peserta didik sebagai impelemntasi professional learning untuk generasi usia emas. Dari dimensi sikap, pendidik melaksanakan workshop dengan penuh kedisiplinan. Keaktifan pendidik dalam workshop cukup baik. Adapun sisi kekurangannya adalah masih ada beberapa pendidik yang tidak berhasil menyusun perencanaan pembelajaran sesuai waktu yang telah ditentukan. Khusus untuk pendidik seperti itu, peneliti memberikan treatmen pembinaan tambahan berupa reviu pembinaan dan memberikan tambahan waktu untuk menyelesaikan tugas dalam penyusunan perencanaan pembelajaran. 
Sebagai bukti ketercapaian atau tidaknya kegiatan worksop peningkatan pendidik profesional dalam implementasi professional learning untuk generasi usia emas di SMP Prakarya, pengabdi sebagai nara sumber/fasilitator melaksanakan penilaian produk perencanaan pembelajaran yang dibuat setiap pendidik. Indikator penilaian kompetensi pendidik profesional dalam perencanaan pembelajaran adalah sebagai berikut. (1) menentukan identitas mata pelajaran; (2) menentukansStandar kompetensi; (3) menentukan kompetensi dasar, (4) menentukan indikator pencapaian kompetensi; (5) menentukan tujuan pembelajaran; (6) menentukan materi ajar; (7) menentukan alokasi waktu; (8) menentukan metode pembelajaran; (9) menentukan kegiatan pembelajaran; (10) menentukan penilaian pembelajaran, dan (11) menentukan sumber belajar.

Berikut ini adalah hasil workshop peningkatan kompetensi pendidik dalam menyusun perencanaan pembelajaran di SMP Prakarya tampak pada tabel 2.1 berikut.

Tabel 2.1

Hasil Workshop Peningkatan Kompetensi Pendidik Dalam Menyusun Perencanaan Pembelajaran Di SMP Prakarya Santi Asromo

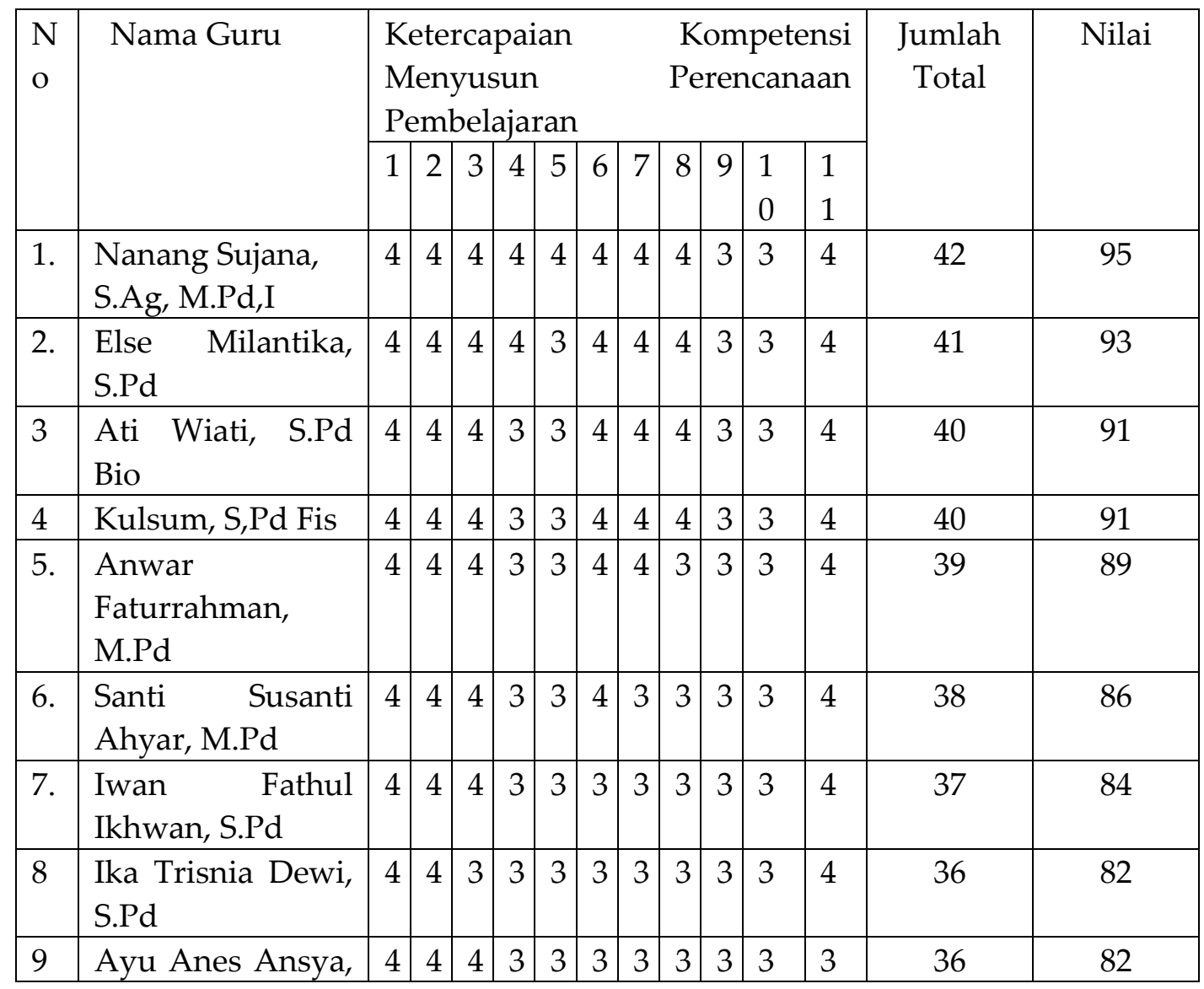




\begin{tabular}{|c|c|c|c|c|c|c|c|c|c|c|c|c|c|}
\hline & S.Pd & & & & & & & & & & & & \\
\hline $\begin{array}{l}1 \\
0\end{array}$ & $\begin{array}{l}\text { Lia Erlina } \\
\text { Marliantini, S.Pd }\end{array}$ & 4 & 4 & 3 & 3 & 3 & 3 & 3 & \begin{tabular}{l|l}
3 & 3
\end{tabular} & 3 & 3 & 35 & 80 \\
\hline $\begin{array}{l}1 \\
1 .\end{array}$ & Khozin, S.Ag & 4 & 4 & 3 & 3 & 3 & 3 & 3 & \begin{tabular}{l|l}
3 & 3 \\
\end{tabular} & 3 & 3 & 35 & 80 \\
\hline $\begin{array}{l}1 \\
2,\end{array}$ & $\begin{array}{l}\text { Ekananda Deis } \\
\text { Noerhuda, S.Pd }\end{array}$ & 4 & 3 & 3 & 3 & 3 & 3 & 3 & \begin{tabular}{l|l}
3 & 3
\end{tabular} & 3 & 3 & 34 & 77 \\
\hline $\begin{array}{l}1 \\
3 .\end{array}$ & $\begin{array}{l}\text { Listia Irni Zahra, } \\
\text { S.Pd }\end{array}$ & 4 & 3 & 3 & 3 & 3 & 3 & 3 & \begin{tabular}{l|l}
3 & 3 \\
\end{tabular} & 3 & 3 & 34 & 77 \\
\hline $\begin{array}{l}1 \\
4 .\end{array}$ & $\begin{array}{l}\text { Diah Sri } \\
\text { Wulansari, S.Pd }\end{array}$ & 4 & 3 & 3 & 2 & 3 & 3 & 3 & 33 & 3 & 3 & 33 & 76 \\
\hline $\begin{array}{l}1 \\
5 .\end{array}$ & $\begin{array}{l}\text { Hari Fikri } \\
\text { Rustiawan, ST }\end{array}$ & 4 & 3 & 3 & 2 & 2 & 3 & 3 & 3 & 3 & 3 & 32 & 73 \\
\hline & \multicolumn{11}{|l|}{ Jumlah Total } & \multicolumn{2}{|c|}{552} \\
\hline & \multicolumn{11}{|l|}{ Rata-rata } & \multicolumn{2}{|c|}{83.73} \\
\hline
\end{tabular}

\section{Keterangan :}

1. Menentukan identitas mata pelajaran

2. MenentukansStandar kompetensi

3. Menentukan kompetensi dasar

4. Menentukan Indikator Pencapaian Kompetensi

5. Menentukan tujuan pembelajaran

6. Menentukan materi ajar

7. Menentukan alokasi waktu

8. Menentukan metode pembelajaran

9. Menentukan kegiatan pembelajaran

10. Menentukan penilaian pembelajaran

11. Menentukan sumber belajar

Berdasarkan hasil in service oleh peneliti dalam bentuk workshop seperti tersebut di atas, nampaknya bahwa workshop secara umum dapat memberikan kontribusi besar terhadap peningkatan profesionalisme tenaga pendidik di SMP Prakarya Santi Asromo. Peningkatan tersebut terlihat pada: Pertama, kompetensi pendidik dalam merencanakan pembelajaran termasuk memahami landasan pendidikan untuk kepentingan pembelajaran. Komperensi ini memiliki indikator esensial bahwa pendidik: (a) memahami landasan kependidikan; (b) menerapkan teori belajar dan pembelajaran; (c) menentukan strategi pembelajaran berdasarkan karakteristik peserta didik, kompetensi yang ingin dicapai, dan materi ajar serta; (d) menyusun rancangan pembelajaran berdasarkan strategi yang dipilih. 
Kedua, kompetensi pendidik dalam merancang dan mengevaluasi pembelajaran. Kompetensi ini memiliki indikator esensial bahwa pendidik mampu: (a) merancang dan melaksanakan evaluasi proses dan hasil belajar secara berkesinambungan dengan berbagai metode; (b) menganalisis evaluasi proses dan hasil belajar untuk menentukan tingkat ketuntasan belajar (mastery learning); dan memanfaatkan hasil penilaian pembelajaran untuk perbaikan kualitas program pembelajaran secara umum.

Hasil tersebut di atas relevan dengan hasil penelitian Sudiana yang menyatakan bahwa kompetensi guru SMP Negeri 2 Sukasada dalam pembelajaran berbasis TIK dapat ditingkatkan melalui pembimbingan dengan workshop dan tanggapan guru SMP Negeri 2 Sukasada terhadap usaha peningkatan kompetetensi guru dalam pembelajaran berbasis TIK melalui pembimbingan dengan workshop dan mentoring dengan katagori positif.[12]

\section{Hasil On Service (Observasi Kelas) dan Pembahasannya}

Dalam rangka penjaminan bahwa pendidik profesional melaksanakan professional learning untuk generasi usia emas diperlukan on service oleh peneliti. Peneliti sebagai akademisi perlu menjamin pendidik profesional dalam implementasi professional learning untuk generasi usia emas. Pengabdi perlu menjamin bahwa hasil workshop dapat dimplementasikan di kelas-kelas oleh pendidik. Tidak jarang bahwa pendidik pasca mengikuti workshop di sekolah hanya menjadi pengetahuan saja, kurang diimplementasikan pada pembelajaran di kelas atau walaupun diimplementasikan hanya diterapkan sekali saja, dua kali dan selanjutnya kembali "seperti dulu lagi. Pendidik kembali seperti biasanya mengajar dominan menggunakan metode ceramah sesekali tanya jawab dan diskusi.

Berdasarkan persoalan seperti tersebut di atas, maka on service pengabdi diperlukan sebagai penjaminan diimplementasikannya hasil workshop di kelaskelas oleh semua guru secara berkelanjutan. Bentuk on service adalah peneliti melaksanakan observasi kelas untuk semua guru. Observasi kelas merupakan salah satu cara paling baik memberikan supervisi pembelajaran karena dapat melihat guru, peserta didik dan masalah yang muncul di kelas-kelas.

Pelaksanaan observasi kelas dilaksanakan melalui pra observasi, observasi, dan pasca observasi.Pada tahap praa observasi kelas peneliti memberitahu kepada pendidik untuk menyiapkan segala sesuatu yang diperlukan untuk diobservasi. Setelah ada kesepakatan jadwal, pendidik diminta untuk mengisi format pra observasi dan memberikan Rencana Pelaksanaan Pembelajaran (RPP) yang digunakan pada saat diobservasi. Peneliti selanjutnya menelaah RPP yang telah diberikan oleh guru yang akan diobservasi.

Pada tahap observasi kelas, peneliti : (a) memberi salam kepada pendidik dan peserta didik di kelas, (b) mencari tempat duduk yang tidak mencolok; (c) 
tidak boleh menegur kesalahan guru di dalam kelas; (d) mencat setiap kegiatan yang dilakukan pendidik dan peserta didik; (e) Memakai alat bantu seperti kamera; (f) mengisi instrumen pelaksanaan pembelajaran dengan check list.

Berikut ini adalah hasil observasi kelas tentang kemampuan pendidik dalam melaksanakan pembelajaran yang berbasis implementasi professional learning untuk generasi usia emas seperti tampak pada tabel 2.2 berikut.

Tabel 1.2

Hasil Observasi Kelas Peningkatan Kompetensi Pendidik Dalam Melaksanakan Pembelajaran Di SMP Prakarya

\begin{tabular}{|c|c|c|c|c|c|c|c|c|c|c|c|c|c|}
\hline \multirow[t]{2}{*}{ No } & \multirow[t]{2}{*}{ Nama Guru } & \multicolumn{10}{|c|}{ Aspek Yang Diamati } & \multirow{2}{*}{$\begin{array}{c}\text { Jumlah } \\
\text { Total }\end{array}$} & \multirow[t]{2}{*}{ Nilai } \\
\hline & & 1 & 2 & 3 & 4 & 5 & 6 & 7 & 8 & 9 & $\begin{array}{l}1 \\
0\end{array}$ & & \\
\hline 1. & $\begin{array}{l}\text { Nanang Sujana, } \\
\text { S.Ag, M.Pd,I }\end{array}$ & 4 & 2 & 3 & 9 & 5 & 5 & 2 & 4 & 2 & 6 & 42 & 95 \\
\hline 2. & Else Milantika, S.Pd & 4 & 2 & 3 & 9 & 5 & 5 & 2 & 4 & 2 & 6 & 42 & 95 \\
\hline 3 & Ati Wiati, S.Pd Bio & 4 & 2 & 3 & 9 & 5 & 5 & 2 & 3 & 1 & 6 & 41 & 93 \\
\hline 4 & Kulsum, S,Pd Fis & 4 & 2 & 3 & 9 & 5 & 5 & 2 & 4 & 2 & 5 & 40 & 91 \\
\hline 5. & $\begin{array}{l}\text { Anwar } \\
\text { Faturrahman, M.Pd }\end{array}$ & 4 & 2 & 3 & 9 & 5 & 4 & 3 & 4 & 2 & 3 & 39 & 87 \\
\hline 6. & $\begin{array}{l}\text { Santi Susanti Ahyar, } \\
\text { M.Pd }\end{array}$ & 3 & 0 & 3 & 9 & 5 & 5 & 1 & 4 & 2 & 5 & 38 & 86 \\
\hline 7. & $\begin{array}{l}\text { Iwan Fathul Ikhwan, } \\
\text { S.Pd }\end{array}$ & 3 & 1 & 3 & 9 & 5 & 5 & 1 & 4 & 2 & 4 & 37 & 84. \\
\hline 8 & $\begin{array}{l}\text { Ika Trisnia Dewi, } \\
\text { S.Pd }\end{array}$ & 3 & 1 & 3 & 9 & 5 & 5 & 1 & 4 & 1 & 4 & 36 & 82 \\
\hline 9 & $\begin{array}{l}\text { Ayu Anes Ansya, } \\
\text { S.Pd }\end{array}$ & 3 & 0 & 3 & 9 & 5 & 4 & 2 & 4 & 2 & 4 & 36 & 82 \\
\hline 10 & $\begin{array}{l}\text { Lia } \\
\text { Marliantini, S.Pd }\end{array}$ & 2 & 1 & 3 & 9 & 5 & 5 & 1 & 4 & 2 & 4 & 36 & 82 \\
\hline 11. & Khozin, S.Ag & 3 & 1 & 3 & 9 & 5 & 3 & 1 & 4 & 2 & 4 & 36 & 82 \\
\hline 12 & $\begin{array}{l}\text { Ekananda Deis } \\
\text { Noerhuda, S.Pd }\end{array}$ & 2 & 2 & 3 & 9 & 5 & 3 & 1 & 4 & 2 & 3 & 34 & 77 \\
\hline 13. & $\begin{array}{lll}\text { Listia Irni Zahra, } \\
\text { S.Pd } & & \\
\end{array}$ & 3 & 0 & 3 & 7 & 5 & 3 & 3 & 4 & 2 & 3 & 33 & 75 \\
\hline 14. & $\begin{array}{l}\text { Diah Sri Wulansari, } \\
\text { S.Pd }\end{array}$ & 4 & 0 & 3 & 9 & 5 & 3 & 0 & 4 & 2 & 2 & 32 & 73 \\
\hline 15. & Hari $\quad$ Fikri & 3 & 0 & 3 & 9 & 5 & 3 & 0 & 3 & 2 & 4 & 32 & 73 \\
\hline
\end{tabular}




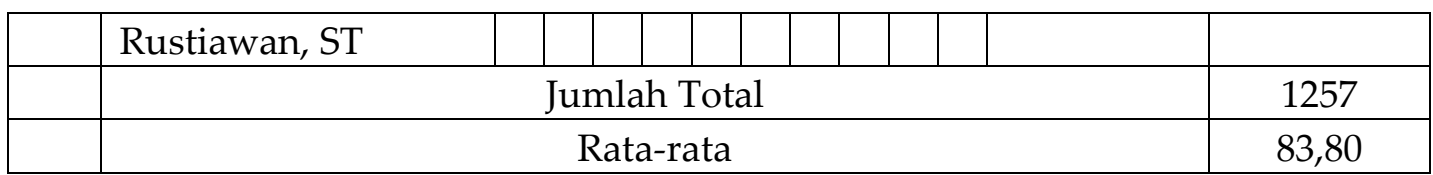

Keterangan:

\section{Kegiatan Pendahuluan}

1. Apersepsi dan Motivasi (4)

2. Penyampaian kompetensi, rencana kegiatan, dan penilaian (3)

\section{Kegiatan Inti}

3. Penguasaan materi pelajaran (3)

4. Penerapan strategi pembelajaran yang mendidik (9)

5. Penerapan pendekatan saintifik (5)

6. Pemanfaatan media/sumber belajar dalam pembelajaran (5)

7. Pelaksanaan penilaian pembelajaran (3)

8. Pelibatan peserta didik dalam pembelajaran (4)

9. Penggunaan bahasa yang benar dan tepat dalam pembelajaran (2)

\section{Kegiatan Penutup}

10. Penutup pelajaran (6)

Berdasarkan data di atas, melalui data instrumen penilaian rencana pelaksanaan pembelajaran dan hasil penilaian observasi kelas menunjukkan bahwa hasil pembinaan pendidik di SMP Prakarya tampak pada tabel 2.3 sebagai berikut.

Tabel 2.3

Hasil Pembinaan Guru Dalam Implementasi Professional Learning

\begin{tabular}{|c|l|c|c|}
\hline No & \multicolumn{1}{|c|}{ Komponen Pembinaan Guru } & Nilai & Katagori \\
\hline 1. & Pembinaan Guru Dalam Menyusun RPP & 83,73 & Baik \\
\hline 2. & $\begin{array}{l}\text { Pembinaan Guru Dalam Melaksanakan } \\
\text { Pembelajaran }\end{array}$ & 83,80 & Baik \\
\hline Jumlah & 167,53 & \\
\hline \multicolumn{2}{|l|}{ Rata-rata } & 83,77 & Baik \\
\hline
\end{tabular}

Berdasarkan tabel 2.3 dapat dijelaskan sebagai berikut. Hasil pelaksanaan pembinaan guru dalam merencanakan pembelajataran rata-rata 83,73 dan hasil pembinaan guru dalam melaksanakan pembelajaran 83,80. Rerata hasil pembinaan guru dalam implementasi professional learning adalah 83,77.

Untuk lebih jelasnya hasil pembinaan guru di SMP Prakarya Kabupaten Majalengka dapat terlihat pada grafik 2.1 berikut. 


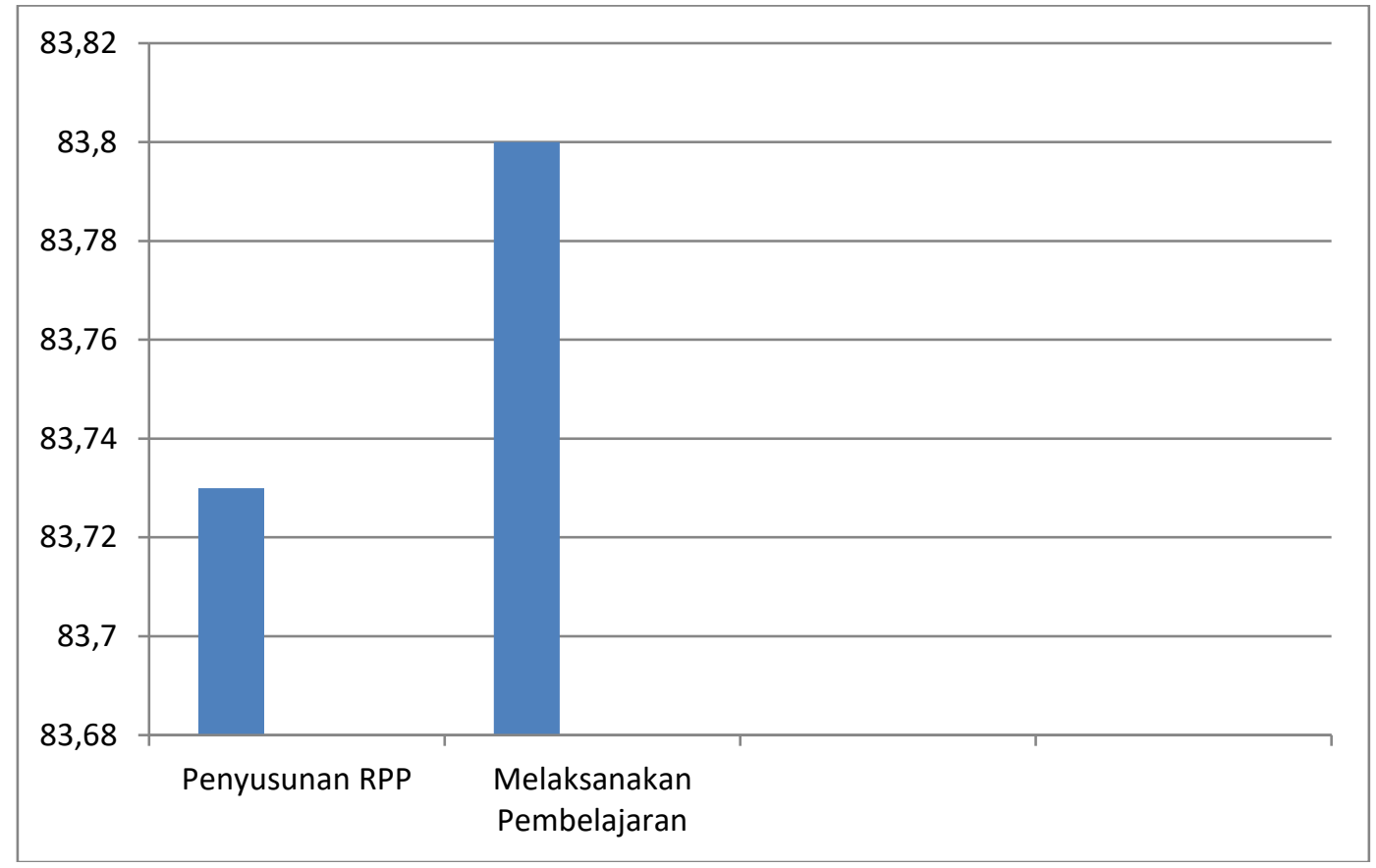

Grafik 2.1

Hasil Pembinaan Pendidik di SMP Prakarya Santi Asromo Kabupaten Majalengka

Berdasarkan uraian di atas, bahwa pelaksanaan on service oleh peneliti dalam bentuk observasi kelas di SMP Prakarya berdampak pada peningkatan pendidik profesional dalam implementasi professional learning untuk generasi usia emas. Peningkatan pendidik profesional dalam implementasi professional learning tampak dalam peningkatan kompetensi pedagogik pendidik terutama dalam pelaksanaan pembelajaran. Selain itu berdampak pula pada peningkatan mutu proses dan hasil pembelajaran peserta didik. Seperti dalam bidang Matematika salah satu peserta didik dari sekolah ini sukses mewakili Kabupaten Majalengka dalam ajang Olimviade Sain Nasiomal tingkat Provinsi Jawa Barat. Dengan demikian bahwa metode observasi kelas sebagai model inovatif efektif dapat meningkatkan pendidik profesional dalam implementasi professional learning untuk generasi usia emas di SMP Prakarya. Namun demikian tantangan selanjutnya mesti ada terutama dalam hal menjaga komitmen pendidikan yang bermutu khususnya bagi para pendidik tentang pentingnya implementasi professional learning untuk generasi usia emas secara berkelanjutan.

Hasil penelitian ini relevan dengan hasil penelitian Suryani bahwa pelaksanaan observasi kelas yang didahului dengan penyusunan program supervisi, melaksanakan supervisi kelas, dan melakukan tindak lanjut dapat 
meningkatkan guru profesional dan juga mutu proses dan hasil pembelajaran.[13] Penelitian ini juga relevan juga dengan hasil penelitian Rachmawati yang menyatakan bahwa supervisi pendidikan yang dilakukan sepertti oleh kepala sekolah berpengaruh positif dan signifikan terhadap perubahan kinerja guru.[14] Kinerja guru akan dapat ditingkatkan bila supervisi pendidikan kepala sekolah dalam bentuk kepemimpinan dan pengawasan ditingkatkan.

Berkaitan dengan keberhasilan tersebut di atas, peneliti sebagai akademisi perlu menjawab tantangan tersebut, sebagai penjaga dan penjaminan pendidikan yang bermutu sejatinya perlu terus eksis dan tidak boleh parkir ataupun berhenti untuk mengawal pendidikan yang bermutu secara berkelanjutan.Seperti dengan metode pembinaan "MIOS" ini perlu terus dilakukan karena metode ini diyakini efektif sebagai model pengembangan keprofesian berkelanjutan pendidik yang inovatif, ekonomis dan lestari.

Implementasi pembinaan dengan metode ini peneliti merasakan sebagai pengalaman terbaik karena telah mampu membangkitkan warga sekolah perlunya pendidik profesional dalam impelemntasi professional learning untuk generasi usia emas. Metode pembinaan "MIOS" yang tawarkan tampaknya sekolah merespon yang luar biasa terbukti sekolah mendukung dan memfasilitasi pelaksanaan program pembinaan dengan metode "MIOS" . Sebagai akademisi pengabdi merasa bangga dan bahagia karena telah hadir membantu dan memfasilitasi penyeleasian persoalan sekolah tentang kinerja pendidik terutama di sekolah swasta yang sering terabaikan pembinaannya karena berbagai persoalan.

Tidak berlebihan bila peneliti menyatakan bahwa metode pembinaan "MIOS" ini terbukti efektif berdampak pada pendidik profesional dalam implementasi professional learning untuk generasi usia emas di SMP Prakarya Santi Asromo. Selain itu, karena langkah-langkah metode pembinaan ini dilaksanakan secara inovatif, ekonomis, leastari dan tidak seperti biasa dilakukan oleh peneliti lain. Hal inilah dirasakan menjadi pengalaman terbaik(best practice) peneliti sebagai akademisi.

Selanjutnya, pada bagian akhir pembahasan ini sewajarnya bila pengadi menyatakan bahwa metode pembinaan "MIOS" ini dapat menjadi inspirasi peneliti/pengadi lain, pengawas sekolah dan kepala sekolah dalam pengembangan keprofesian berkelanjutan (PKB) bagi guru di sekolah karena model ini terbukti dapat meningkatkan pendidik profesional dalam implementasi professional learning untuk generasi usia emas.

\section{Kesimpulan}

Berdasarkan hasil pengembangan Model MIOS dalam peningkatan pendidik professional dalam implementasi professional learning untuk generasi usia emas, maka simpulan yang dapat dipaparkan adalah sebagai berikut. 
Pertama, monitoring sebagai kegiatan tahap awal treatment peneliti di SMP Prakarya Santi Asromo menunjukkan bahwa implementasi professional learning untuk generasi usia emas belum berjalan dengan optimal di SMP Prakarya Santi Asromo. Hambatannya adalah adanya keragaman kompetensi pedagogik guru dalam perencanaan dan pelaksanaan pembelajaran dalam implementasi professional learning untuk generasi usia emas. Keragaman tersebut tampak pada kemampuan guru dalam perancangan dan pelaksanaan pembelajaran. Hasil monitoring ini menunjukkan bahwa faktor penyebab keragaman kemampuan guru tersebut adalah karena keragaman kualifikasi akademik guru, terbatasnya kegiatan pengembangan keprofesian berkelanjutan guru, dan komitmen guru dalam peningkatan mutu masih rendah serta tidak dilaksanakan supervisi kelas oleh kepala sekolah. Hasil monitoring ini sebagai pintu masuk untuk pembinaan pendidik professional secara berkelanjutan berdasar kebutuhaan pendidik itu sendiri.

Kedua, berdasarkan hasil in service oleh peneliti sebagai nara sumber dalam bentuk workshop secara umum dapat memberikan dampak terhadap peningkatan profesionalisme pendidik di SMP Prakarya Santi Asromo, yaitu: (1) kompetensi pendidik dalam merencanakan pembelajaran termasuk memahami landasan pendidikan untuk kepentingan pembelajaran. Kompetensi ini memiliki indikator esensial dalam implementasi professional learning untuk generasi usia emas bahwa pendidik: (a) memahami landasan kependidikan; (b) menerapkan teori belajar dan pembelajaran; (c) menentukan strategi pembelajaran berdasarkan karakteristik peserta didik, kompetensi yang ingin dicapai, dan materi ajar serta; (d) menyusun rancangan pembelajaran berdasarkan strategi yang dipilih; (2) kompetensi pendidik dalam merancang dan mengevaluasi pembelajaran. Kompetensi ini memiliki indikator esensial dalam implementasi professional learning untuk generasi usia emas bahwa pendidik mampu: (a) merancang dan melaksanakan evaluasi proses dan hasil belajar secara berkesinambungan dengan berbagai metode; (b) menganalisis evaluasi proses dan hasil belajar untuk menentukan tingkat ketuntasan belajar (mastery learning); dan memanfaatkan hasil penilaian pembelajaran untuk perbaikan kualitas program pembelajaran secara umum.

Ketiga, Pelaksanaan on service oleh peneliti dalam bentuk observasi kelas di SMP Prakarya Santi Asromo berdampak pada peningkatan pendidik profesional dalam implementasi professional learning untuk generasi usia emas. Peningkatan pendidik profesional dalam implementasi professional learning tampak dalam peningkatan kompetensi pedagogik pendidik dalam pelaksanaan pembelajaran di kelas-kelas. Selain itu berdampak pula pada peningkatan mutu proses dan hasil pembelajaran peserta didik. Salah satu dampaknya adalah dalam bidang Matematika yang mana salah satu peserta didik dari sekolah ini sukses mewakili kabupaten dalam ajang Olimviade Sain Nasiomal Tingkat Provinsi Jawa Barat. 


\section{Referensi}

[1] Aminah, Khairuddin, Husen, M. 2012. Pembinaan Kompetensi Profesional Guru Oleh Kepala Sekolah Pada SMP Negeri 2 Kota Sigli. Jurnal Administrasi Pendidikan ISSN 2302-0156 Pascasarjana Universitas Syiah Kuala, 1 (13) Hlm. 1-13.

[2] Anto 2019. Pembinaan Kompetensi Guru [Online] Tersedia di: https://sman1 pasirpenyu.sch.id/read/9/pembinaan-kompetensi-guru.

Diaakses tanggal 3 April 2021.

[3] Darmadi, H. 2015. Tugas, Peran, Kompetensi dan Tanggung Jawab Menjadi Guru Profesional. Jurnal Edukasi, 13 (2), Hlm. 161-174.

[4] Ediana, A. 2015. Implementasi Professional Learning Untuk Anak Usia Emas.Jakarta: UIN Syarif Hidayatullah.

[5] Kementerian Pendidikan dan Kebudayaan 2017. Panduan Kerja Pengawas Sekolah Pendidikan Dasar dan Menengah. Jakarta: Kemdikbud.

[6] Kementerian Pendidikan dan Kebudayaan 2019. Supervisi Akademik. Jakarta: Kemdikbud.

[7] Nasution, S. 2005. Didaktik Asas-Asas Mengajar. Bandung: Bumi Aksara

[8] Rahmawati, T. 2016. Supervisi Pendidikan Sebagai Upaya Meningkatkan Kinerja Guru. Jurnal Coopetition, 7 (1), Hlm. 43 -52

[9] Ratnasari, Y.T. 2019. Proseding Seminar Nasional "Profesionalisme Guru Dalam Peningkatan Mutu Pendidikan". Pada Jurusan Administrasi Pendidikan Fakultas Ilmu Pendidikan Universitas Negeri Malang Revitalisasi Manajemen Pendidikan Anak Usia Dini (PAUD) di Era Revolusi Industri 4.0. Hlm. 235-239.

[10] Rusman 2010. Model-Model Pembelajaran. Bandung: Mulia Mandiri Press

[11] Slam, Z. 2015.Peningkatan Kompetensi Pustakawan Dalam Menyusun Program Perpustakaan Sekolah Melalui Mini Lokakarya Di SMPN 1 Jatiwangi Kabupaten Majalengka. Majalengka: Disdik.

[12] _ 2015. Pembelajaran Gotong Royong Inovatif Berbasis Soft Skll dan Hard Skill Untuk Mewujudkan Indonesia Emas. Jakarta: UIN Syarif Hidayatullah Jakarta.

[13] Sudiana, N. 2019. Implementasi Tindak Lanjut Hasil Supervisi Akademik untuk Meningkatkan Kompetensi Guru dalam Pembelajaran Berbasis TIK Melalui Pembimbingan dengan Shoping. Journal of Education Action Research, 3 (4) pp. 410-417.

[14] Suprayekti dan Septyara Dwi Anggraen, S.D., 2017. Pelaksanaan Program Workshop "Belajar Efektif" Untuk Orang Tua. Jurnal Ilmiah VISI PGTK PAUD dan DIKMAS, 12 ( 2), Hlm. 129-136. 
22 - Zaenul Slam

[15] Suryani, C. 2015. Implementasi Supervisi Pendidikan Dalam Meningkatkan Proses Pembelajaran Di MIN Sukadamai Kota Banda Aceh. Jurnal Ilmiah Didaktika, 116 (1), Hlm. 23-43.

[16] Triwiyanto, T. 2015. Pelaksanaan Monitoring, Evaluasi, dan Pelaporan Untuk Penilaian Kinerja Manajerial Kepala Sekolah. Jurnal Cakrawala Pendidikan, 34 (1), Hlm. 67-77.

[17] Wijaya, C.A. 2018. Sistem Monitoring dan Evaluasi Pengelolaan Program Studi di Institusi Pendidikan Tinggi. Indonesian. Journal of Information Systems (IJIS), 1(1). Hlm. 13-24. 